\title{
Millennial Thoughts from Central and Eastern Europe
}

\author{
By Christina Stojanova
}

Fall 1999 Issue of KINEMA

Where is that fragile line between different cultures, different religions, different national or personal identities?

- Agnieszka Holland

THE 19th CENTURY politician Metternich, a champion of Western European isolationism and Austrian xenophobia, is credited with saying that Asia begins at the Landstrasse, that is, at the street that leads out of Vienna toward Hungary. Over the last two hundred years of our millennium, Central and Eastern European countries have struggled to overcome this deep prejudice and reclaim their place in Europe independent political and cultural entities. And while it has been very difficult to do so in terms of economic and political modernisation; in terms of establishing long lasting state and social institutions that are capable of generating and perpetuating democracy, in terms of culture Central and Eastern European countries have scored much more successfully. In fact, often times much better than their Western European counterparts. Ten years after the fall of Communism, notwithstanding the financial hurdles caused by the dismantling of state support for cinema, the Central and Eastern European program, presented at this year's festivals in Montreal and Toronto, looked rather encouraging in terms of its vitality, professionalism and intensive moral concern. A new generation of film-makers, born in the first half of the 1960s, is taking quickly centre-stage. And while the masters are still engaged in exploring the Communist and post-Communist legacy ${ }^{(1)}$, the films of the middle-aged and young directors are treating themes and personages that, without losing their local identification and character, are much closer and comprehensible for the Western viewer. According to their films, Central and Eastern Europeans seem to be affected by millennial contemplations and ideas that are to be found in the works of film-makers across the globe. And if I am allowed to summarise these contemplations and ideas, I would call them essays on the encounters with the God within. These sublime encounters, however, are not represented in any spectacular or mysterious fashion. They usually occur in mundane surroundings and with ordinary people, and most often result in moral revelations or extraordinary acts of love and personal sacrifice. A Christ-like figure could be the central character and agent of the sublime transformation or could also, through her/his suffering, become a catalyst for the moral transformation of the principal character(s).

Certainly, the much argued Cannes award winner L'humanité by French director Bruno Dumont; the Montreal film festival favourite, the Grand prix des Amériques winner La couleur du paradis, by Iranian director Majid Majidi; the Israeli film Kadosh (Amos Gitai) and The Third Miracle (dir. Agnieszka Holland) fit into the above outline. Even the Québécois film Souvenirs Intimes (Jean Beaudin) could loosely be added to this list. The suffering, the redemption and the sacrificial motifs are incorporated through the complex interpretation of another biblical archetype - that of the Madonna and her illegitimate child.

It is hardly necessary to mention that evoking biblical metaphors and archetypes results in works that are politically and socially heavily charged. In the cases of the above mentioned films, however, the confessional affiliation of the characters does not play a decisive role. Their spirituality is distinctly separated from the ritualised religion and is seen as something deeply personal and intimate whose only expression is unconditional love for your fellow human being(s). They could be Muslim as in The Colour of God, or adhere to ultra-orthodox Judaism as in Kadosh or be ardent Catholics as in The Third Miracle or be atheists as in L'humanité and Souvenirs Intimes. In any case, the role of the institutionalised religion as the sole symbol and repository of spirituality is either subdued and or even rendered hostile, as is the rigour of the rabbi in Kadosh. Through his principal characters - a pious scholar of the Talmud and his equally pious and loving wife - the director of Kadosh (which in translation means "holy") carefully juxtaposes the institutionalised and the innermost types of spirituality. Believed barren, Rifka is forced to leave her husband so that he could marry another woman to bear him a child. After weeks of silent suffering, she violates the proscription and comes home to die in the arms of her husband who still loves her dearly. The director prefers to pose questions instead of offering answers and easy solutions to this tragic dilemma. Even the fate of Rifka's sister who leaves the community as she cannot bear a life without love in a forced marriage, 
represents only another paraphrase of the same eternal question: is the love for God and the love for another human really irreconcilable?

Agnieszka Holland's American film The Third Miracle attempts to answer this question by representing the spiritual transformation of a derelict priest (Ed Harris), reluctantly involved in the process of examining miracles that could eventually lead to the canonising of a new saint. Holland made her name as a politically engaged film-maker with a sharp sense for the moral and existential paradoxes of totalitarianism, both as a script-writer for A. Wajda ${ }^{(2)}$ and as a director in her own right. ${ }^{(3)}$ She continued her passionate explorations into (im) possible forms of spiritual freedom in a repressive society with her films, made in the West ${ }^{(4)}$. In To Kill a Priest (1988), the Catholic faith was represented as the ultimate expression of spiritual dissidence in Communist Poland, and in Total Eclipse (1995), it was the open homosexual love between the poets Rimbaud and Verlaine in turn-of-the century France. With The Third Miracle, she revokes her inside knowledge of the Catholic church, her interest in possibilities for spiritual survival, and brings in a distinctly Eastern European motif: the prospective saint is a Gypsy woman from Slovakia who was brought to America as a child immediately after the war. Not long before her emigration, during an Allied bomb raid, the little Gypsy girl miraculously saved her native town with a passionate prayer, delivered on the stairs of the town cathedral.

The case proves difficult to be contained within the canon of the institutionalised faith as the potential candidate is an immigrant woman of simple faith and of no theological sophistication. Her unspectacular life, however, was entirely devoted to the destitute youth in a harsh Chicago neighbourhood and even after her death her marble statue continues to protect them by shedding tears of blood with miraculous healing power. The fact that the prospective saint left her own beloved daughter (Anne Heche) at the tender age of sixteen in order to be able to serve better God and those who needed her more - prostitutes, molested children, drug addicts - makes her case more complicated. Finally, the case is resolved positively as the investigative priest himself replicates the woman's thorny path to redemption: through his passionate love for her daughter, his spirituality is awoken and rediscovers God. In the name of God, however, he sacrifices his love for the daughter in order to be able to serve better those who need him more. ${ }^{(5)}$

With her film Simon, the Magician, another famous woman film-maker from the middle generation, the Hungarian Ildiko Enyedi, offers her musings about the nature of spirituality on the eve of the millennium in a co-production, sponsored by the French-based company Eurimages. Enyedi became a celebrity with her picturesque meditation on the miracles of history and technology in "her" 20th century as witnessed by her generation (My 20th Century, 1989).

Appropriately for the millennium mood, Enyedi evokes the biblical figure of Simon the Sorcerer and for a good reason. She sees the need for miracles not as a deeply personal foment for soul-searching but as a fashionable source for self-delusion, manipulated by the media. In her view, miracles are a sensational substitute for the spiritual deficiency at the very end of our 20th century. Equally appropriately the miracles, performed by her Simon, are of quite a different nature from those, performed by Holland's humble heroine. He does not stop bombs from falling, does not cure and does not console the destitute, he is a rather pragmatic psychic who resolves high-profile murder cases world-wide and asks for high fees up-front, in cash and in hard currency. Quite like his infamous predecessor who offered to purchase from the Apostles Peter and John the supernatural power of transmitting the Holy Spirit and thus preserved himself the infamous place in the Bible as the archetypal heretic and the first trader of holy relics, or 'simonite'.

Enyedi's hero shares the chameleon features of his mythic predecessor who, at the dawn of our aeon, succeeded to appear to the Jews as a suffering "Son of God"; to his native Samaritans as "Father" and to the pagan world as the "Holy Spirit." Simon, the Hungarian psychic, is much better off than the original Simon: he does not to have to preach as the media does the job for him. For the media-crazed Parisians, he is what they are told he is although noone has really seen his psychic methods at work.

However, Enyedi's Simon, in the brilliant interpretation of the famous Hungarian actor Peter Andorai ${ }^{(6)}$ is a complex personality: he is a charming introvert; a middle-aged loner, dressed with an old-fashioned chic. He does not waste words and therefore everything he chooses to say sounds wise. He is most likely a decent person and even a genuine sorcerer although the evidence is scant. Here the director apparently relies on other early Christian writings, according to which Simon is believed to be the first Gnostic who advocated 
salvation through secret wisdom and magical arts. On the other hand, it does not really matter whether Simon is wise or endowed with magic powers. After all, people interpret his passive, somewhat amorphous personality as a screen, where they could see projected their most intimate desires and fears. Thus the culprit in the murder under investigation succumbs to the aura of the supernatural and sheepishly signs a confession almost immediately after Simon gets involved with the case. Quite unexpectedly, Simon falls in love with a beautiful and lonely Parisian university student he sees at the train station. The fact that he quietly follows her everywhere, never takes his eyes off her and answers her numerous questions with 'yes' or 'no', the only French words he knows, releases her imagination and curiosity. His gentle nature allows her to see in him everything she wants to see: a father figure, an exotic, romantic lover, an intellectual partner and a spiritual leader - all in one. Simon's timidity and unobtrusive wisdom attract a young black policeman who is ready to leave the force and follow him as a disciple.

Finally, Simon's uncomplicated presence triggers the deep seated insecurity in his rich and complacent rival, a fellow Hungarian, who challenges him to a sorcer's duel. According to another Christian legend, Simon the Sorcerer appeared in Rome in the first century AD to challenge Apostle St. Peter, and fell to his destruction in an attempt to demonstrate his occult ability to fly. In a similar way, Simon the Hungarian accepts the challenge of his rival to spend three days buried and rise on the third day in a Christ-like fashion. Simon's one and only attempt to perform a 'real' miracle is evidently inspired by his newly found love and by the urgency of this all-pervasive spiritual deficiency. It also comes as a proof of his natural decency and compassion. Predictably, the resurrection fails and Simon apparently dies of suffocation. However, his disciple, his beloved, the media and everyone around refuse to part with their illusions and go on waiting for the miracle to happen. On this ambiguous note Enyedi concludes the film.

Biblical metaphors and archetypes are used by contemporary directors not only to evoke spiritual and moral issues, but also as plain narrative devices, meant to mobilise the collective unconscious and keep the attention of the viewers. While the four films by young film-makers from Central and Eastern Europe presented at the Montreal film festival, demonstrate willingness to embrace risks of experimentation on the level of visual form and gender representation, they are careful not to upset the viewer on level of narrative. ${ }^{(7)}$ Especially interesting is the shift in constructing masculinity vis-à-vis the so-called 'male democracy' that has emerged in the Communist aftermath. All four films definitely challenge the fashionable macho image that has been constructed in series of Central and Eastern European films over the last decade. The favourite type is the hero from the Mafiosi thriller: a young to middle-aged male, whose wealth usually comes from shady dealings, bordering on criminality. He is usually countered by a lonely policeman, a Film Noir type, who usually fights a losing battle not in the name of society and justice, but in the name of his personal ideals or simply to get even. ${ }^{(8)}$ There is yet a third type of male hero who inhabits the claustrophobic world of the small auteur films. He is usually a passive intellectual who is trying to cope with the profound changes, brought about by the fall of Communism. This type of hero is usually the director's protagonist, and his quest represents a flight to some imaginary paradise (his parents' country house, for example) ${ }^{(9)}$; to another woman or a plunge into bouts of self-reflection, accompanied by drinking or joy rides. ${ }^{(10)}$ The protagonist of the elegantly crafted black-and-white Slovene film Idle Running, first feature for its director Janez Burger, fits perfectly into this category. Although Dizi eloquently defends his life-style of dolce far niente as a conscientious objection against what he eloquently defines as an 'universal obsession with hyper activity, change and (re) production', he is actually just another infantile egoist who lives off the two women who are in love with him.

It is interesting to examine how the film Close to Love by the young Hungarian director Andras Salamon, presented at the official competition of the Montréal film festival, constructs masculinity and incorporates biblical metaphors. It introduces a hero who is active, but is not macho. Karczi is a country boy who comes to Budapest and enthusiastically joins the police force not out of complex ideological considerations but because he likes fast cars and life in the capital. By incorporating into his character features that are traditionally considered feminine - nurturing, sensitivity and general concern for his fellow human beings the film-maker constructs him as a charming outsider who is perceived harmless and is generally liked by everyone: by his bullish buddies for patiently putting up with their practical jokes and by his no-nonsense boss for his efficiency and decency.

Everything however changes when Karczi falls in love with a pretty Chinese girl, in trouble with the police. 
It remains unclear whether the source of her troubles is her torn passport, her links to organised crime or something even more sinister. We are only allowed to learn that she is pregnant and the father has disappeared, most likely deported back to China. The point of view is that of the hero, and it does not allow for a better comprehension of the girl's explanations (she only speaks Chinese) or of her motifs - whether she truly loves him or, as Karczi's colleagues believe, is just using him. The director concentrates on the growing intensity of Karczi's love for the girl and her unborn baby. An intensity that makes him confront his xenophobic and misogynist colleagues, risk his life and ultimately sacrifice his career.

This story could have been filmed just about anywhere in our increasingly cognate world and yet it is powerfully Hungarian. It proves that cinema remains part of a larger cultural horizon, characterised by overlapping local, regional. national, and global institutions that grow increasingly deterritorialised. This explains why, in spite of the unlikely Chinese connection in the heart of Budapest; or the car-chases and nudity, there is nothing exotic about the film. Its harsh documentary visuals, hand-held camera and penchant for the back yards and the seedy neighbourhoods of Budapest keeps it firmly rooted in its concrete time and space. Evidently, Salamon belongs to the new and still rare kind of post-Communist film-makers who believe that popular success is not a synonym for an artistic compromise. Therefore the resolution he chooses for the love story does not conform to the requirements of realism or to the limitations of existing geographical and cultural stereotypes, but with the expectations of the viewer. What ultimately pulls the narrative together and makes it transcend its limitations, is another unwavering biblical archetype - that of Joseph, the ultimate symbol of sacrificial paternity, and his Holy Family. The film closes with Karczi and his ethnically mixed holy family leaving the maternity ward and disappearing into the uncertainties of the frosty Budapest dawn.

By contrast, young Bulgarian director Andrei Slabakov belongs to the staunchly auteur brand of Central and Eastern European directors. He seems to insist with every shot of his first feature film Wagner that accessibility and artistism as prerogatives of 'low' and 'high' art, respectively, are at irreconcilable and perennial odds. An elitist conviction that has shaped Central and Eastern European culture over the last two centuries.

In a series of nightmarish hyperbolas, the film reveals the life of an average working woman in Bulgaria. Elena (starring Ernestina Shinova, the director's wife), works in a dingy factory where she operates an ominous and loud pre-war piece of German machinery, called Wagner (therefrom the name of the film). Like her female colleagues, she engages routinely in sexual intercourses with her boss that seem to provoke neither indignation nor pleasure in her. One day, Elena is summoned and told that, after eleven years on the waiting list, and in recognition of her hard work, she is finally granted a subsidised housing. She sets off to inspect her long awaited apartment, located in a pompous Stalinist building with marble stairs and high ceilings, and this is where all the hell breaks loose. The tenants of the apartment building represent a Kafkaesque panoptikum who look strangely familiar. Like vampires, they attack the innocent and humane Elena and subject her to all kinds of mental and physical tortures and she willingly offers herself in an earnest attempt to satisfy their real or imaginary needs and thus relieve them from their suffering.

The director veils thinly his cruel metaphor of a society that has seized to produce any positive energies and preys viciously on those rare saintly creatures who believe that the meaning of life is in giving generously. Slabakov resorts to apocalyptic biblical metaphors, and constructs his own version of hell on earth. The representation of Elena as the sacrificial lamb thus serves an important narrative function but most of all an important social and gender function.

The film-maker has assembled Wagner from random bits and pieces of cultural signifiers, taken out of their historical context and therefore suggesting that nothing has really changed in Bulgaria after the fall of Communism. The events could have happened anytime between the Communist take-over in 1944 and the present day. And, indeed, according to statistics, the post-Communist 'male democracy' has only worsened the lot of women, relegating them to the most disadvantaged social strata. On this backdrop, Elena's graphical suffering loses its metaphorical value and becomes a very authentic account of all the forms of misogyny and abuse that exist in the post-Communist world.

As in Wagner, the Christ-like figure also serves the role of a moral standard in the other two films by young film-makers (Le retour de l'idiot; The Return of the Idiot by Czech director Sasha Gedeon and Junction, first feature of Polish woman film-maker Urszula Urbaniak). The fact that both films cast the Christ-like 
characters as people, defined as deranged and therefore socially marginalised, plays a vital structural and ethical role. For his film, Gedeon mobilises yet another religious/cultural archetype - that of Dostoevsky's Idiot. Like him, and like the saint's daughter in The Third Miracle, Gedeon's hero appears in the life of the 'normal' people to help them learn more about themselves, and resolve their self-destructive dilemmas. The 'normal' characters in the film represent a strange quartet of two brothers and two sisters, entangled in a complex emotional relationship. One day, the 'idiot', a distant relative of the brothers, returns from a closed institution for mental patients where he had undergone complex and severe treatment over many years. Although the nature of his suffering is not clear, it appears that his acute sense of right and wrong, and almost organic inability to compromise and to lie, have rendered him totally unfit for the 'real' life of market economy and laissez-fair morality in the post-Communist world. His status of a disabled outsider allows him to watch over the promiscuous exchanges amongst the foursome, enclosed in the claustrophobic settings of crowded and overheated Prague apartments, where one can bring a date on the rare occasion of absence of his/her parents and siblings. Like Simon, the Magician, the 'idiot' does not even try to directly interfere in these entangled relationships. His very presence however turns him into an apparition of the characters' neglected conscience. And like Simon, the Magician, Gedeon's film remains ambivalent as to whether anyone or anything would change after the idiot has left.

The post-modern ambiguity of the moral message and absence of narrative closure, endemic for all films discussed so far, persist in Junction (Special Mention by the City of Montreal jury). Urbaniak's young heroines, Krystina and Adela, inhabit a god-forgotten dwelling, neither town nor village, whose only raison d'etre is the railway junction. While Adela works at the junction, Krystina uses it as a meeting place with her numerous lovers. For both girls life at home is worse than prison and their only hope for salvation is finding the right suitor. While Adela is romantic and passive, the sexy and practical Krystina keeps inventing new strategies for breaking into the big and rich life they have only heard of. The girls' retarded classmate is desperately in love with Adela and his otherwise irritating presence seems to protect her from reckless attempts to imitate Krystina's ill-fated designs. The idea to merge the biblical archetype of the Guardian Angel with the cultural figure of the village idiot reveals the moral frustration in a post-Communist society where archetypal symbols of hope and stability are treated as synonyms of social marginality and backwardness. At the end of the film, the pregnant Krystina, after being raped and humiliated by a local thug, is being forced into a loveless marriage. At the same time, an ambulance is taking the village idiot to be, equally forcibly, locked away in an institution. Adela is finally free from the presence of her competitive friend and from her unwanted Guardian Angel. The question however remains: free for what? For all she faces now, as the characters from Wagner and The Return of the Idiot, is a spiritual and moral void where the old is no more and the new looks dangerously unclear.

\section{Notes}

1. In his latest opus, La Lanterne du seigneur a Budapest (Lord's Lantern in Budapest), Miklós Jancsó is attempting a stream-of-consciousness narrative about the human condition at the edge of the millennium. The master himself appears in key sequences to reveal his most intimate fears of old age and death (he will be 80 in 2001). His existential musings are intertwined with bitter reflections on life in post-Communist Hungary and its masters, seen as profoundly immoral, deranged and trigger-happy crooks. The film does offer some startlingly sarcastic sketches, targeting the new rich and the new poor, as well as some wittingly visualised philosophical metaphors on the brevity and fragility of life, borrowed from the Bible and Hamlet. It however remains confusingly hermetic even by Jancsó's standards.

Another Eastern European master, Vojtěch Jasný, also offers his auto-biographical revelations, but in a simpler narrative form. The cinematic protagonist of Le retour au paradis perdu (Which Side Eden), selected for competition at the Montreal film festival, revisits the country he has left after the Soviet tanks crashed the Prague Spring in 1968. Just like the director himself, the hero was once a celebrated Czechoslovak New Wave film-maker and just like him, he presently enjoys a successful career at the New York film school. Unlike Jancsó's dark contemplation, however, Jasný's film is full of optimism and brightness. Everyone on both sides of the ocean is pleased with life, and happy to help his fellow human beings: the police, the homeless and the media join efforts to find the protagonist's nine-year-old nephew, lost in New York. At 
home, in the village portrayed with so much tenderness and harsh realism in All My Countrymen (1967), the old animosities and betrayals are forgotten, and communists and dissidents are happily singing in the church choir.

In this line of thought, it is interesting to compare how prominent directors tackle another legacy of postCommunism: the ethnic divisions and the ensuing civil wars. In Checkpoint, The Russian A. Rogozhkin offers a forceful interpretation of the conflict on the Caucasus. In tune with the pacifist pathos of another famous work on the subject, S. Bodrov's Prisoner of the Mountains (1996), he represents the young conscripts and the local Muslim population as victims of somebody else's clashing interests. The Croat K. Papic, known for his dissident films from the 1970s, sees the Yugoslav war in his Quand les morts se mettent a chanter in artistically traditional and politically chauvinist terms, as an inevitable conflict between the good Croats and the evil Serbs. His Yugoslav counterpart, the famous actor Lazar Ristovski (Underground, Baril de poudre) has chosen for his first film Le costume blanc not only the principal role of an officer from the morally and finacially bankrupt Yugoslav Army but also a carnivalesque (or rather Kusturica-esque) cinematic style that ridicules the suicidal militarism of Belgrade.

2. Man of Marble (1976) and Without Anaesthesia (1977).

3. Among others, Provincial Actors (1979) and Woman on Her Own (1981).

4. Other films Holland made in the West include Europa, Europa (1990); Oliver, Oliver (1991); The Secret Garden (1993) and Washington Square (1997).

5. While Ed Harris is respectfully professional, but a bit inflexible in the role of the investigative priest, it is Anne Heche's ephemeral beauty and delicate charm that bring out the spirituality not only in Harris's hero, but also in the film. Thus Holland's decision to challenge Hollywood's tradition in gender representation by inviting an openly gay actress for the role of a saint's daughter and a priest's beloved, pays off.

6. Somewhat clumsy and overweight; with his introvert sensitivity and insecurity, bordering on weakness and betrayal that served him so well in István Szabó's Colonel Redl (1983) and Sweet Emma, Dear Böbe (1992), Andorai scores well against generally accepted screen representations of masculinity and charisma.

7. Understandably, under the apparent pressure and commercial concerns of their Western producers, the films of Holland and Eneydi stick to a more or less conventional form and style. Their well-known taste for experimentation is channelled, and the mystique of their otherwise pretty straightforward narratives, are foregrounded forcefully in the stunning visuals of Jerry Zielinsky and Tibor Mathe, respectively.

8. Among others, the Polish films Pigs I (1992) and Pigs II: The Last Blood (1995); Amok (1999); the Russian films Music for December (1995) and Brother (1997).

9. The Slovak film The Garden (1996) comes to mind, as well as the Bulgarian Summer with a Loser (1992) and Something in the Air (1994).

10. The Czech films The Ride (1994) and Indian Summer (1995) are the best examples in this category.

\section{Author Information}

Christina STOJANOVA teaches at the Department of Media Production and Studies at the University of Regina, Canada. She has contributed to Cine-bulles, KinoKultura, and the Montreal Gazette. Her publications include chapters in Berlin Culturescapes, Making it Like a Man: Canadian Masculinities, Eastern European Cinema, Traditions in World Cinema, Horror International, Alternative Europe and Cinema and Globalization. 